\title{
BMJ Open British Columbia CARMA-CHIWOS Collaboration (BCC3): protocol for a community-collaborative cohort study examining healthy ageing with and for women living with HIV
}

Shayda A Swann (1) ,,2 Angela Kaida, ${ }^{2,3}$ Valerie Nicholson, ${ }^{3,4}$ Jason Brophy, ${ }^{5}$ Amber R Campbell, ${ }^{2,6}$ Allison Carter, ${ }^{3,7}$ Chelsea Elwood, ${ }^{2,8}$ Tsion Gebremedhen, ${ }^{3}$ Rebecca Gormley, ${ }^{3,4}$ Elizabeth M King, ${ }^{2,9}$ Melanie Lee, ${ }^{3}$ Vonnie Lee, ${ }^{2,6}$ Evelyn J Maan, ${ }^{2,6}$ Patience Magagula, ${ }^{10}$ Sheila Nyman, ${ }^{11}$ Davi Pang, ${ }^{3}$ Neora Pick, ${ }^{2,12}$ Tetiana Povshedna, ${ }^{13}$ Jerilynn C Prior, ${ }^{2,14}$ Joel Singer, ${ }^{15}$ Shelly Tognazzini, ${ }^{3}$ Melanie C M Murray, ${ }^{2,12}$ Helene C F Cote ${ }^{2,13}$

To cite: Swann SA, Kaida A, Nicholson V, et al. British Columbia CARMA-CHIWOS Collaboration (BCC3): protocol for a community-collaborative cohort study examining healthy ageing with and for women living with HIV. BMJ Open 2021;11:e046558. doi:10.1136/ bmjopen-2020-046558

- Prepublication history and additional supplemental material for this paper are available online. To view these files, please visit the journal online (http://dx.doi.org/10.1136/ bmjopen-2020-046558).

MCMM and HCFC contributed equally.

MCMM and HCFC are joint senior authors.

Received 03 November 2020 Accepted 22 July 2021

Check for updates

(C) Author(s) (or their employer(s)) 2021. Re-use permitted under CC BY-NC. No commercial re-use. See rights and permissions. Published by BMJ.

For numbered affiliations see end of article.

Correspondence to

Dr Helene C F Cote;

hcote@pathology.ubc.ca

\section{ABSTRACT}

Introduction Women living with HIV (WLWH) experience accelerated ageing and an increased risk of ageassociated diseases earlier in life, compared with women without HIV. This is likely due to a combination of viral factors, gender differences, hormonal imbalance and psychosocial and structural conditions. This interdisciplinary cohort study aims to understand how biological, clinical and sociostructural determinants of health interact to modulate healthy ageing in WLWH. Methods and analysis The British Columbia Children and Women: AntiRetroviral therapy and Markers of AgingCanadian HIV Women's Sexual and Reproductive Health Cohort Study (CARMA-CHIWOS) Collaboration (BCC3) study will enrol WLWH $(n=350)$ and sociodemographically matched HIV-negative women $(n=350)$ living in British Columbia. A subset of BCC3 participants will be past participants of CARMA, $n \geq 1000$ women and children living with and without HIV, 2008-2018 and/or CHIWOS, $\mathrm{n}=1422$ WLWH, 2013-2018. Over two study visits, we will collect biological specimens for virus serologies, hormones and biological markers as well as administer a survey capturing demographic and sociostructuralbehavioural factors. Sociodemographics, comorbidities, number and type of chronic/latent viral infections and hormonal irregularities will be compared between the two groups. Their association with biological markers and psychostructural and sociostructural factors will be investigated through multivariable regression and structural equation modelling. Retrospective longitudinal analyses will be conducted on data from past CARMA/ CHIWOS participants. As BCC3 aims to follow participants as they age, this protocol will focus on the first study visits. Ethics and dissemination This study has been approved by the University of British Columbia Children's and Women's Research Ethics Board (H19-00896). Results will be shared in peer-reviewed journals, conferences and at community events as well as at www.hivhearme.ca and @ HIV_HEAR_me.WLWH are involved in study design, survey
Strengths and limitations of this study

- This study takes an interdisciplinary 'cell-to-society' approach to understanding healthy ageing in women living with HIV by considering cellular markers of ageing, hormonal influences and psychosocial/ structural factors and interactions between these factors.

- Women living with HIV and community partners representing key populations in British Columbia are meaningfully involved in the planning, knowledge generation and implementation of this research.

- As this study enrols participants from two other well-established cohorts across Canada, we will have up to 10 years of longitudinal data for a subset of participants.

- This study is inclusive to cis-women and transwomen, but not cis-men. Sex-based analyses may be pursued, numbers permitting.

- As this study only considers women living in British Columbia, a setting with access to free HIV treatment, the degree to which findings can be generalised to other settings is to be determined.

creation, participant recruitment, data collection and knowledge translation. A Community Advisory Board will advise the research team throughout the study.

\section{INTRODUCTION}

Since the introduction of combination antiretroviral therapies (cART) in 1996, people living with HIV (PLWH) are less likely to die from AIDS-related illnesses and more likely to be affected by chronic diseases. ${ }^{1-3}$ PLWH are also living longer, highlighting the need to support healthy ageing, including 
maintaining functional ability, access to health resources, autonomy, empowerment, social relationships, mental and spiritual well-being, freedom from stigma and sense of purpose. ${ }^{45}$ The prevalence and incidence of HIV in older Canadians have increased, with $45 \%$ of new diagnoses in 2018 occurring in people $\geq 50$ years. ${ }^{6}$ In the western Canadian province of British Columbia (BC), there were 6556 PWLH $\geq 50$ years in 2019 , comprising the greatest proportion $(61.8 \%)$ of total cases. ${ }^{7}$

Globally, there are $\sim 18.8$ million women living with HIV (WLWH), comprising $\geq 50 \%$ of PLWH. ${ }^{8}$ In Canada, women represent 23\% of the 63110 PLWH and their proportion has steadily increased over the past 35 years, comprising $\sim 30 \%$ of new infections in $2018 .{ }^{6}$ In BC, there were $>11000$ PLWH in $2017,18 \%$ of whom were women. ${ }^{9}$ Indigenous people comprised $4.9 \%$ of BC's population in $2017,{ }^{10}$ yet Indigenous women constituted $33 \%$ of new infections among women. ${ }^{9}$

Sex and gender impact women's risk for acquiring HIV as well as morbidity and mortality risk following HIV acquisition. ${ }^{11-13}$ In Canada, WLWH have poorer health outcomes across the HIV care cascade compared with men, including lower rates of access to care and adherence to cART, ${ }^{14}{ }^{15}$ more comorbidities ${ }^{16-18}$ and higher mortality rates. ${ }^{19} 20$ WLWH also experience significant psychological stressors, including gender-based violence, substance use, discrimination, the impacts of colonisation and isolation. ${ }^{21-23}$ These may further accelerate biological ageing and its health impacts. Even though WLWH live 5-10 years less than women without HIV and 7 years less than men living with $\mathrm{HIV},{ }^{19}$ there is a paucity of research on why this occurs. ${ }^{24}$ Studies that primarily focus on men are not generalisable to women. Importantly, healthy ageing has been identified as a key research priority among WLWH. Understanding whether and how living with HIV uniquely affects ageing among women requires disentangling the effects of HIV alongside biomedical and sociostructural factors.

The British Columbia Children and Women: AntiRetroviral therapy and Markers of Aging-Canadian HIV Women's Sexual and Reproductive Health Cohort Study (CARMA-CHIWOS) Collaboration (BCC3) is an interdisciplinary partnership between two cohorts of WLWH. CARMA is a pan-Canadian cohort of $>1000$ WLWH and their children, with sociodemographically matched HIVnegative women. CARMA studied the effects of HIV and cART on biochemical markers of ageing. CHIWOS is a pan-Canadian community-based research study examining women-centred HIV care and the sexual, reproductive and mental health outcomes of 1422 WLWH in BC, Ontario and Quebec. ${ }^{25}$ BCC3 brings the expertise of these cohorts to comprehensively evaluate biochemical, clinical and sociobehavioural-structural factors that interact to modulate ageing in WLWH. Here, we describe the aims, cell-to-society methodology, ${ }^{26}$ and community-based framework of the cross-section portion of the BCC3 study. We hypothesise that chronic viral infections and/or hormone dysregulation will (a) impact markers of cellular ageing in
WLWH, and that (b) these effects will intersect with sociostructural factors to affect comorbid illness. Results will both guide clinical practice and inform policy, to improve health outcomes for WLWH throughout the life course.

\section{Factors that modulate women's healthy ageing}

Ageing is modulated by numerous biological and sociostructural processes. Understanding the role of these factors and their interactions is critical to our aims.

\section{Chronic/latent viral infections}

WLWH are at risk for coinfection with other chronic/ latent viral infections, such as hepatitis C virus (HCV), ${ }^{27} 28$ hepatitis B virus (HBV), ${ }^{29}$ herpes simplex virus, ${ }^{30} 31$ cytomegalovirus ${ }^{2731}$ and human papillomavirus. ${ }^{32}{ }^{33}$ Chronic/ latent viral infections are those that persist for life or until treatment with curative therapies. ${ }^{34}$ These infections often coexist due to similar routes of transmission and sociostructural conditions, such as injection drug use or sexual contact ${ }^{35} 36$ and can impact the immune system, leading to immune senescence and chronic inflammation. ${ }^{37-39}$ It is currently unknown how coinfections with chronic/latent viruses impact ageing in WLWH.

\section{Cellular ageing}

Chronic inflammation and oxidative stress contribute to cellular ageing and development of age-related comorbidities (ie, cardiovascular disease, type 2 diabetes etc) ${ }^{40-42}$ Key markers of ageing include immune cell subset distribution, mitochondrial DNA (mtDNA) mutations/heteroplasmy and leucocyte telomere length (LTL) ${ }^{4344}$ Immune cell activation in response to chronic/latent viral infections shifts the balance between cell subsets, affecting the body's ability to fight pathogens or malignancies. ${ }^{45} 46$ Mitochondria are central to metabolism, energy production and hormone synthesis. mtDNA is particularly susceptible to damage and mutagenesis ${ }^{44}$; as mutations accumulate, pathological mtDNA heteroplasmy (the presence of different mtDNA species) and accelerated ageing occur. ${ }^{47}$ Among WLWH, high HIV plasma viral loads and tobacco smoking have been associated with changes in mtDNA levels, higher mtDNA mutations and heteroplasmy, ${ }^{48}$ but very little is known about the effects of psychosocial stressors on mtDNA. HIV itself decreases mtDNA levels, while some antiretrovirals are implicated in mitochondrial toxicity and mtDNA damage. ${ }^{49}$ cART can modulate mtDNA levels, especially at initiation and interruption, promoting clonal amplification of mutations. It remains unclear how cART interruptions, planned or not, may affect cellular ageing.

Telomeres are protective caps at the ends of DNA chromosomes. ${ }^{44}$ Shorter LTL is a predictor of cellular ageing and age-related morbidities, such as cardiovascular disease ${ }^{50}$ CARMA demonstrated that PLWH have shorter telomeres than people without $\mathrm{HIV},{ }^{51}$ which may partially explain the accelerated/accentuated ageing phenotype seen in this population. ${ }^{52}$ Indeed, cells infected with chronic/latent viruses may lose telomeres at 
higher rates. ${ }^{53}$ Immune senescence occurs when immune cell telomeres shorten past a critical length. Senescent cells can no longer divide but are proinflammatory and contribute to disease. The proportion of senescent CD8 $\mathrm{T}$ lymphocytes (ie, CD8 +CD28 T cells) increases with chronic/latent viral infections ${ }^{53}$; however, it is unknown if these changes relate to the development of comorbidities in WLWH and how they are influenced by psychosocial factors.

\section{Hormonal and reproductive health}

WLWH experience disproportionate rates of amenorrhea (ie, lack of menstruation), early menopause and other endocrine abnormalities. ${ }^{54-56}$ In the CHIWOS cohort, $56 \%$ of WLWH reported abnormal menstruation. ${ }^{55}$ In the CARMA cohort, $58 \%$ of WLWH had at least one endocrine abnormality, which was associated with having a peak viral load $\geq 100000$ copies $/ \mathrm{mL} .{ }^{57}$ Ovarian steroids, including estradiol and progesterone, assist in maintaining bone ${ }^{58-60}$ renal, ${ }^{61-63}$ hepatic, ${ }^{2064} 65$ metabolic ${ }^{66}{ }^{\text {cognitive }}{ }^{67}$ and cardiovascular health. ${ }^{68}$ Estradiol also counteracts cellular ageing by preserving mitochondrial function ${ }^{69}$ and telomere length. ${ }^{70}$ Opioid use, ${ }^{71}$ post-traumatic stress disorder (PTSD), ${ }^{72}$ smoking $^{73}$ and chronic stress can all contribute to endocrinopathies. ${ }^{775}$ Furthermore, the CHIWOS study demonstrated that WLWH are rarely asked about their reproductive health by care providers, ${ }^{76}$ further exacerbating stigma and poor reproductive health outcomes. Although it has been established that WLWH have a high burden of agerelated comorbidities, the role of hormones and social factors in ageing remains unclear.

\section{Sexual health}

Healthy ageing includes positive, stigma-free experiences of sex and relationships. ${ }^{77} 78$ Due to stigma, stress and gender inequity, negative outcomes in sexuality and reproduction are common, including unintended pregnancies and sexual dissatisfaction. Despite decisive evidence that there is no risk of sexual HIV transmission in those who maintain an undetectable viral load, ${ }^{79} 49 \%$ of WLWH in the CHIWOS cohort were sexually inactive. ${ }^{80}$ Understanding these barriers will enable providers to support women's sexual health as they age.

\section{Intersecting determinants of health}

Ageing is further modulated by sociostructural stressors, including adverse childhood events, discrimination, gender-based violence, housing and food insecurity, income inequality, substance use, smoking, lack of education, poor access to health services, impacts of COVID-19 and intergenerational impacts of colonisation. ${ }^{81-83} \mathrm{~A}$ gender-based approach is critical to understanding how these factors interact with cellular and hormonal factors to shape women's ageing experience. For instance, many WLWH have survived forced sex or childhood trauma, which has been associated with shorter LTL, ${ }^{84}$ depression, post-traumatic stress and other mental health concerns

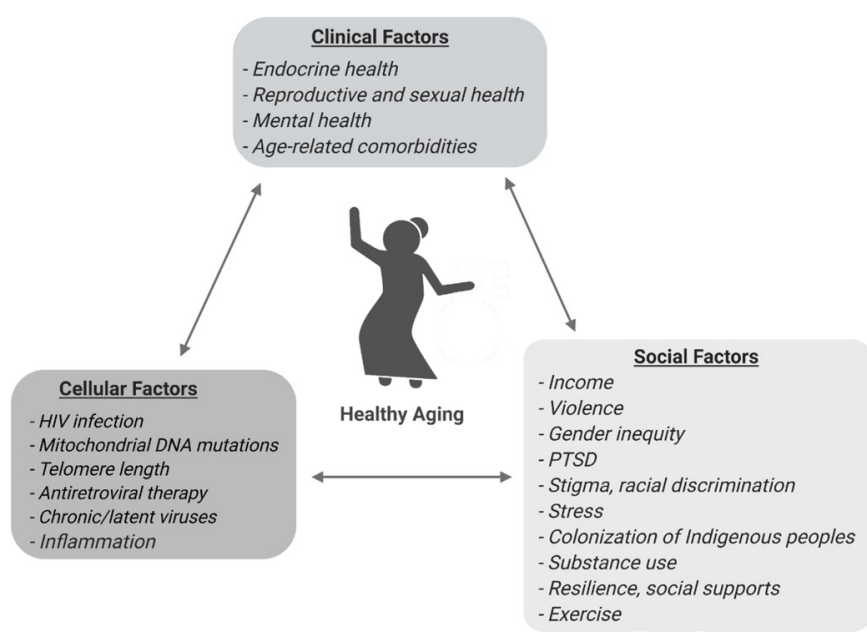

Figure 1 Interacting factors in women's healthy ageing. PTSD, post-traumatic stress disorder.

in adulthood. ${ }^{85}{ }^{86}$ Mental health concerns may intersect with substance use, very low body fat, nutritional deficiencies and extreme stress-all risk factors for hypothalamic amenorrhea. Subsequent low oestrogen predisposes to numerous illnesses (ie, osteoporosis, cardiovascular disease) and mitochondrial and telomere decline. Substance use may result in coinfection with other chronic/latent viruses, exacerbating oxidative stress and cellular ageing. None of these factors exists in isolation (figure 1).

\section{Study aims}

We seek to address the following aims:

- To characterise and compare (1) comorbidities, (2) the burden of chronic/latent viral infections, (3) endocrine health/irregularities, (4) age of menopause, (5) psychosociostructural factors, (6) sexual and reproductive health and (7) markers of cellular ageing and inflammation in WLWH and HIV-negative women.

- To determine the modulating effects of treatment interruption, changes in cART regimens and HCV clearance on our outcome measures of interest.

- To investigate how the measures of interest (aim 1) interact to modulate women's experiences of healthy ageing.

\section{Overarching aim}

To nurture meaningful involvement of community in basic and clinical science research, integrate communitycollaborative methods and build capacity in communitybased research.

\section{Study design}

Patient and public involvement statement

Meaningful involvement of members of the HIV community is central to BCC3. Women of Indigenous, African, Caribbean and Black ancestry, transwomen, im/migrant and refugee women and women with histories of injection drug use and/or engagement in sex work are 
Table 1 Description of historical CHIWOS (2013-2015) and CARMA (2008-2018) participant characteristics at baseline

\begin{tabular}{ll} 
CHIWOS-British Columbia & CARMA \\
\hline WLWH & WLWH \\
$(\mathrm{N}=356)$ & $(\mathrm{N}=275)$
\end{tabular}

\section{HIV-negative}

$(\mathrm{N}=291)$

\begin{tabular}{|c|c|c|c|}
\hline \multicolumn{4}{|l|}{ Sociodemographics } \\
\hline Age (years), median (IQR) & $44(37-51)$ & $40(34-47)$ & $43(32-55)$ \\
\hline \multicolumn{4}{|l|}{ Education, $\mathrm{n}(\%)^{\star}$} \\
\hline Less than high school graduation & $93(26 \%)$ & $93(34 \%)$ & $61(21 \%)$ \\
\hline High school graduation or greater & $260(73 \%)$ & $162(59 \%)$ & $226(78 \%)$ \\
\hline Don't know/prefer not to answer† & $3(1 \%)$ & $20(7 \%)$ & $3(1 \%)$ \\
\hline \multicolumn{4}{|l|}{ Income, n (\%)‡ } \\
\hline$<15$ 000/y (CARMA); <\$20,000/y (CHIWOS) & $282(79 \%)$ & $135(49 \%)$ & $121(42 \%)$ \\
\hline$\geq \$ 15,000 / y$ (CARMA); $\geq 40$ 000/y (CHIWOS) & $53(18 \%)$ & $125(45 \%)$ & $168(58 \%)$ \\
\hline Don’t know/prefer not to answer† & $5(3 \%)$ & $15(5 \%)$ & $2(<1 \%)$ \\
\hline \multicolumn{4}{|l|}{ Sexual orientation, $\mathrm{n}(\%)$} \\
\hline Heterosexual & $294(83 \%)$ & & \\
\hline LGBTQ2S§ & $61(17 \%)$ & & \\
\hline \multicolumn{4}{|l|}{ Ethnicity, n (\%) } \\
\hline Indigenous-First Nations, Métis or Inuit & $161(45 \%)$ & $77(28 \%)$ & $79(27 \%)$ \\
\hline African/Caribbean/Black & $28(8 \%)$ & $44(16 \%)$ & $15(5 \%)$ \\
\hline White & $139(39 \%)$ & $140(51 \%)$ & $162(56 \%)$ \\
\hline Other and mixed ethnicities $\mathbb{\|}$ & $28(8 \%)$ & $31(11 \%)$ & $51(18 \%)$ \\
\hline \multicolumn{4}{|l|}{ Injection drug use history, $\mathrm{n}(\%)$} \\
\hline Yes & $225(63 \%)$ & $81(29 \%)$ & $33(11 \%)$ \\
\hline No/unknown & $131(37 \%)$ & $194(71 \%)$ & $258(89 \%)$ \\
\hline \multicolumn{4}{|l|}{ Clinical characteristics } \\
\hline Body mass index $\left(\mathrm{kg} / \mathrm{m}^{2}\right)$, mean (SD) & $27(6.8)$ & $27(6.3)$ & $26(6.6)$ \\
\hline Hepatitis C virus infection, $\mathrm{n}(\%)$ & $201(56 \%)$ & $114(41 \%)$ & $49(17 \%)$ \\
\hline Hepatitis B virus infection, $n(\%)$ & $48(13 \%)$ & $17(6 \%)$ & $1(<1 \%)$ \\
\hline Ever/currently on cART, $n(\%)^{\star \star}$ & $318(89 \%)$ & $275(100 \%)$ & \\
\hline \multicolumn{4}{|l|}{ Most recent HIV plasma viral load, $n(\%) \dagger \dagger$} \\
\hline Undetectableł‡ & $286(82 \%)$ & $169(61 \%)$ & \\
\hline Detectable§§ & $51(14 \%)$ & $104(38 \%)$ & \\
\hline Unknown & $13(4 \%)$ & $2(<1 \%)$ & \\
\hline \multicolumn{4}{|l|}{ Most recent CD4 count, $\mathrm{n}(\%) \dagger \dagger$} \\
\hline$<200$ cells $/ \mathrm{mm}^{3}$ & $30(9 \%)$ & $31(12 \%)$ & \\
\hline $200-500$ cells $/ \mathrm{mm}^{3}$ & $114(32 \%)$ & $112(41 \%)$ & \\
\hline$>500$ cells $/ \mathrm{mm}^{3}$ & $166(47 \%)$ & $129(47 \%)$ & \\
\hline Unknown & $42(12 \%)$ & $3(<1 \%)$ & \\
\hline
\end{tabular}

Some ( 130) participants may have been enrolled in both CARMA and CHIWOS.

*Income and education increments differ between CARMA and CHIWOS.

†'Don't know/prefer not to answer' for CHIWOS participants, 'Unknown' for CARMA participants.

$\ddagger$ Canadian dollars/year.

§LGBTQ2S, lesbian, gay, bisexual, transgender, queer or two-spirited.

ПOther ethnicities include Chinese/Filipino/Japanese/Korean/Latin American/Hispanic/Southeast Asian/Arab/West Asian/Multiple ethnicities.

${ }^{\star *}$ Ever on cART in CARMA, currently on cART in CHIWOS.

††HIV viral load and CD4 counts based on self-report in CHIWOS and clinical blood work data in CARMA.

$\ddagger \ddagger H I V$ viral load $<50$ copies $/ \mathrm{mL}$ among CHIWOS participants or $<40$ copies $/ \mathrm{mL}$ among CARMA participants.

$\S \S$ HIV viral load $>50$ copies $/ \mathrm{mL}$ among CHIWOS participants or $>40$ copies $/ \mathrm{mL}$ among CARMA participants.

CARMA, Children and Women: AntiRetroviral therapy and Markers of Aging; cART, combination antiretroviral therapy; CHIWOS, Canadian HIV

Women's Sexual and Reproductive Health Cohort study; WLWH, women living with HIV. 
Table 2 Overview of clinical and community visits

\begin{tabular}{|c|c|c|c|}
\hline & Part 1-clinical visit & Part 2-community visit & Part 3-optional timed hormone visit \\
\hline Location & Oak Tree Clinic, in person & $\begin{array}{l}\text { Community site, in person } \\
\text { or virtually }\end{array}$ & Remote testing or in person \\
\hline $\begin{array}{l}\text { Biospecimens } \\
\text { collected }\end{array}$ & $\begin{array}{l}\text { Venous blood } \\
\text { Urine } \\
\text { Hair } \\
\text { Buccal swab } \\
\text { Rectal swab (self-collected, } \\
\text { optional) }\end{array}$ & & $\begin{array}{l}\text { Venous blood for estradiol and } \\
\text { progesterone measurements in } \\
\text { women who are menstruating }\end{array}$ \\
\hline Visit duration & $1.0-2.0$ hour & $1.0-1.5$ hour & \\
\hline
\end{tabular}

disproportionately affected by HIV in BC. Historically, biomedical research has excluded persons with living and lived experience, using extractive rather than collaborative approaches to data collection and utilisation. These practices are damaging; they preclude valuable insights into community voices and inadequately study the sociocultural lenses that shape health. Women, in particular, have been vastly under-represented in biomedical research, yielding consequences, whereby the health priorities of WLWH are undervalued and underaddressed. ${ }^{24}$ Experiences from the CHIWOS study consistently demonstrate that coproduced knowledge by researchers and community is more accessible, relevant and inclusive of the diverse experiences of WLWH. ${ }^{8788}$ To help address the structural inequities these populations face, we must change the structure of our research teams. Therefore, BCC3 uses a 'research with and for' rather than 'research on' approach, informed by the principles of Greater Involvement of PLWH/AIDS (GIPA), ${ }^{89}$ Meaningful involvement of WLWH/AIDS (MIWA) ${ }^{90} 91$ and Ownership, Control, Access and Possession (OCAP). GIPA and MIWA refer to the rights of PLWH and WLWH to self-determination in knowledge generation, translation and implementation. OCAP refers to the rights of Indigenous communities 'to own, control, access and possess information about their people'. ${ }^{2}$ Given the inherently colonial nature of research practices, histories of unethical research on Indigenous communities in BC and the over-representation of Indigenous WLWH, it is critical that we strive to do research in 'a good way'. 9394 Based on these principles and the framework established in CHIWOS, ${ }^{95} 96$ our community-collaborative study is conducted by, with and for WLWH from study conceptualisation to knowledge translation (see online supplemental table S1).
To honour MIWA and GIPA principles, peer research associates (PRAs), who are essential members of our research team, have been hired, trained and supported, as pioneered by the CHIWOS study. ${ }^{96}$ PRAs are:

self-identified women living with HIV (cis- and transinclusive) who share social identities (eg, Indigenous, racialized, sexual minority, and trans women) and lived experiences (eg, injection drug use, sex work, incarceration, childhood and adulthood violence experiences) with the community of women living with HIV ... ${ }^{96}$

Through an iterative process of consultation, review and implementation, PRAs lend their living and lived experiences, and community expertise, to this project at every step, from study design to data collection and knowledge translation. They completed multiphase experiential training in research ethics, research methods, survey administration, self-care and knowledge translation and studied the biomedical elements of this project. They are engaged in designing data collection instruments to ensure that questions are acceptable, safer, inclusive and relevant to community priorities. For example, community members identified the importance of studying chronic pain in WLWH. As this was not previously in our questionnaire, we worked with PRAs to identify relevant questions now included in the study. PRAs currently assist with recruitment, survey administration and provide leadership in knowledge translation to participants and the wider community. They continue to be invited to lead and coauthor conference presentations and peer-reviewed manuscripts. PRAs coauthored the present article and have presented at local research conferences as well as our inaugural Community Advisory Board (CAB) meeting. Engaging a team of both experienced and novice PRAs 


\section{Table 3 Clinical survey}

\section{Clinical survey} section

\section{Subsections}

Sociodemographics

Immune status (vaccine or natural infection)

$\begin{aligned} \text { Non-HIV medications } & \text { Opiates, vitamins/supplements, } \\ & \text { prescribed and over-the-counter } \\ & \text { medications }\end{aligned}$

HIV medical history Diagnosis, nadir CD4, latest CD4 count, viral load, current/historical ARVs, current/historical ARV side effects, adherence (\%)

$\begin{array}{ll}\text { Medical history } & \text { Diagnoses of and treatment for } \\ \text { specific comorbid medical conditions } \\ \text { (ie, respiratory, renal, cardiovascular, } \\ \text { endocrinological, reproductive, hepatic, } \\ \text { cancer). } \\ \text { Family medical history } \\ \text { Hearing loss, loss of vision, motor } \\ \text { disabilities } \\ \text { Mental health (ie, mood, anxiety, PTSD, } \\ \text { addiction/substance use, neurocognitive, } \\ \text { personality, psychotic, eating disorders } \\ \text { and trauma-related disorders) } \\ \text { Transgender health (ie, hormone therapy, } \\ \text { transition surgery) } \\ \text { Menstrual history, current menstrual } \\ \text { status (ie, duration, frequency, associated } \\ \text { symptoms), symptoms of peri- } \\ \text { menopause/menopause, treatments for } \\ \text { symptoms of menopause, reproductive } \\ \text { organ surgeries, pregnancy/parity/ } \\ \text { spontaneous or medical abortion, use of } \\ \text { fertility services, contraceptive use and } \\ \text { history } \\ \text { Current/historical use of alcohol, } \\ \text { tobacco, cannabis and illegal or legal } \\ \text { drugs not used in the manner for which } \\ \text { they were prescribed; discrimination due } \\ \text { to drug use }\end{array}$

Each item listed under 'subsections' is associated with one or more detailed questions.

ARVs, antiretrovirals; PTSD, post-traumatic stress disorder.

supports mentorship within the team, while expanding PRA capacity building, collaboration and career advancement. PRAs receive financial remuneration $(\$ 25 \mathrm{CAD} /$ hour) for their work and expertise and for attending team meetings.

Consistent with the recommendations of the Canadian Truth and Reconciliation Council for conducting research with Indigenous communities, ${ }^{97} 98$ the BCC3 team is honoured to include two Indigenous Elders with
Table 4 Community survey

\section{Community survey sections}

\section{Subsections}

\begin{tabular}{ll}
\hline Sociodemographics & $\begin{array}{l}\text { Food security, childcare, incarceration } \\
\text { history }\end{array}$ \\
Sleep and oral health & $\begin{array}{l}\text { Sleep quality and quantity, sleep aids, } \\
\text { oral health }\end{array}$
\end{tabular}
oral health

Women's sexual health Sexual history, experiences and history of consensual and nonconsensual sex, relationship history, impacts of HIV on sexual health, experiences of exchanging sex for money/goods/services, experiences of sexual violence, sexual desire/ pleasure/satisfaction

Stigma and

discrimination HIV-related stigma/discrimination, racism, sexism

Physical activity Duration, frequency and intensity

Violence and abuse

Adulthood and childhood experiences of verbal, physical and sexual violence

Social support Relationships with others (ie, visits, advice, love, affection, assistance)

Emotional and social well-being and health

Mental health diagnoses, thought patterns, peer support, quality of life, energy, perceived health, spiritual health, sense of purpose in life

$\begin{array}{ll}\text { Resilience } & \begin{array}{l}\text { Life direction and goals, sense of } \\ \text { accomplishment and determination }\end{array} \\ \text { Impacts of COVID-19 } & \begin{array}{l}\text { Diagnoses; impacts on social life, } \\ \text { healthcare, mental health }\end{array}\end{array}$

Some questions in this section are repeated from the clinical survey as an internal validation measure. For sensitive questions, participants will have the option of completing the section on their own or with a PRA.

PRA, peer research associate.

whom we have long-standing relationships. Elder Valerie Nicholson is Mi'kmaq and Haida, an award-winning researcher, and experienced PRA from the CHIWOS study who will lead our team in Indigenising research. Elder Sheila Nyman is Syilx Metis from the Lower Similkameen in the Okanagan Valley. She has extensive experience working with WLWH as both an elder and a clinical social worker and is available to support our research team and participants.

As a respected leader within African, Caribbean and Black communities, Patience Magagula, Executive Director of Afro-Canadian Positive Network of BC, is a knowledge user on this study to promote the meaningful inclusion and cultural safety of the diverse Black communities of BC. Magagula has worked with our study team to investigate barriers to recruiting members of African, Caribbean and Black communities in HIV research in BC.

In accordance with best-practices in community-based research, the BCC3 study has established a CABconsisting of WLWH, Indigenous Elders, policymakers, HIV/AIDS Service Organisations representatives, 
Table 5 Validated measures in the British Columbia CARMA-CHIWOS Collaboration (BCC3) questionnaire

\begin{tabular}{ll}
\hline Survey item & Validated scale \\
\hline $\begin{array}{c}\text { Comorbidities } \\
\text { Liver fibrosis }\end{array}$ & $\begin{array}{l}\text { Fibrosis-4 score }(\text { cut-off }>1.45)^{111}, \\
\text { aspartate aminotransferase/platelet ratio } \\
\text { (cut-off } \geq 1.2)^{112}\end{array}$
\end{tabular}

Kidney fibrosis, Kidney Failure Risk Equation (cut-off failure

Dyslipidaemia stage $\geq 3$ renal disease) ${ }^{113}$

\section{Canadian Cardiovascular Society} Guidelines $^{114115}$

One or more of: (a) triglycerides $\geq 1.7$ $\mathrm{mmol} / \mathrm{L}$; (b) high-density lipoprotein cholesterol (HDL-C) $\leq 1.3 \mathrm{mmol} / \mathrm{L}$; (c) low density lipoprotein cholesterol (LDL-C) $\geq 5$ $\mathrm{mmol} / \mathrm{L}$; (d) Framingham Risk Score $10 \%-19 \%$ and LDL-C $\geq 3.5 \mathrm{mmol} / \mathrm{L}$ or non-HDL-C $\geq 4.3 \mathrm{mmol} / \mathrm{L}$

And/or answers yes to the question 'do you have high cholesterol or lipids' and/or prescribed lipid medications

\begin{tabular}{|c|c|}
\hline Depression & $\begin{array}{l}\text { Center for Epidemiological Studies } \\
\text { Depression Scale }{ }^{116} \text { (validated in people } \\
\text { living with HIV). }{ }^{117} \text { Positive score is } \geq 10 \\
\text { on a scale of } 0-30\end{array}$ \\
\hline Anxiety & $\begin{array}{l}\text { Generalised Anxiety Disorder 7-item } \\
\text { scale }^{118}\end{array}$ \\
\hline $\begin{array}{l}\text { Post-traumatic } \\
\text { stress disorder } \\
\text { (PTSD) }\end{array}$ & 6-item PTSD checklist, cut-off $\geq 14^{119}$ \\
\hline $\begin{array}{l}\text { Excess/dependent } \\
\text { alcohol use }\end{array}$ & $\begin{array}{l}\text { The 3-item Alcohol Use Disorder } \\
\text { Identification Test }\end{array}$ \\
\hline $\begin{array}{l}\text { Diagnoses such } \\
\text { as such as } \\
\text { liver disease, } \\
\text { kidney disease, } \\
\text { osteoporosis/ } \\
\text { osteopenia, } \\
\text { diabetes, } \\
\text { hypertension, } \\
\text { dyslipidaemia, } \\
\text { cardiovascular } \\
\text { disease, peripheral } \\
\text { vascular disease, } \\
\text { cognitive } \\
\text { impairment and } \\
\text { depression }\end{array}$ & $\begin{array}{l}\text { Canadian Longitudinal Study on Aging } \\
\text { (survey and data publicly available } \\
\text { online })^{121} \text { will be used to compare to the } \\
\text { general Canadian population. }\end{array}$ \\
\hline
\end{tabular}

Sexual and reproductive health

$\begin{array}{ll}\begin{array}{ll}\text { Menopausal and } \\ \text { perimenopausal }\end{array} & \begin{array}{l}\text { Adapted from Women's Health } \\ \text { Interagency HIV Study Menopause } \\ \text { symptoms }\end{array} \\ & \text { Symptoms Questionnaire; }{ }^{122} \text { Study } \\ \text { of Women's Health Across the Nation } & \text { Questionnaire } \\ & \text { Menopause Society Menopause Health } \\ & \text { Questionnaire }\end{array}$

Sexual functioning Adapted from the Brief Index of Sexual Functioning for Women scale, ${ }^{125}$

Sexual satisfaction Adapted from the Sexual Satisfaction Scale for Women ${ }^{126}$

Sexual power Sexual Relationship Power Scale ${ }^{127}$
Table 5 Continued

\begin{tabular}{|c|c|}
\hline Survey item & Validated scale \\
\hline $\begin{array}{l}\text { Physical, verbal, } \\
\text { control and/or } \\
\text { sexual violence }\end{array}$ & $\begin{array}{l}\text { Canadian HIV Women's Sexual and } \\
\text { Reproductive Health Cohort study } \\
\text { (CHIWOS) Questionnaire }^{128}\end{array}$ \\
\hline \multicolumn{2}{|c|}{ Socio-behavioural-structural determinants of health } \\
\hline HIV-related stigma & $\begin{array}{l}\text { 12-item HIV Stigma Scale-Short } \\
\text { Form, }{ }^{129130} \text { CHIWOS Enacted HIV Stigma } \\
\text { Scale }^{131}\end{array}$ \\
\hline $\begin{array}{l}\text { Gender inequity, } \\
\text { racism, sexism }\end{array}$ & 9-item Everyday Discrimination Scale ${ }^{132}$ \\
\hline $\begin{array}{l}\text { Drug use } \\
\text { discrimination }\end{array}$ & Drug Use Discrimination Scale ${ }^{133}$ \\
\hline Social supports & $\begin{array}{l}\text { 19-item Medical Outcome Study Social } \\
\text { Support Score }\end{array}$ \\
\hline Resilience & 10-item Resiliency Scale $e^{135136}$ \\
\hline $\begin{array}{l}\text { Health-related } \\
\text { quality of life }\end{array}$ & $\begin{array}{l}\text { 12-item Short Form Survey/Short Form } \\
\text { Measure of General Health }{ }^{137}\end{array}$ \\
\hline Food security & $\begin{array}{l}\text { Household Food Security Survey } \\
\text { Module }^{138}\end{array}$ \\
\hline Spiritual health & Spiritual Health Scale ${ }^{139}$ \\
\hline $\begin{array}{l}\text { Sense of purpose } \\
\text { in life }\end{array}$ & Oregon Brief Purpose Measure ${ }^{140}$ \\
\hline $\begin{array}{l}\text { Impacts of } \\
\text { COVID-19 }\end{array}$ & $\begin{array}{l}\text { Canadian Longitudinal Study on Aging, }{ }^{121} \\
\text { WHO Survey Tool }\end{array}$ \\
\hline
\end{tabular}

This is not an exhaustive list of all questions in the BCC3 study, but rather those that have come from previously used or validated questionnaires. In some instances, modified/shortened versions of the survey tools are used. The BCC3 survey can be found in it's entirely on our website at https://hivhearmeca/ resources/.

clinicians, researchers and other stakeholders. The CAB, cochaired by one academic and one community representative, meets annually to exchange knowledge, provides insight and ensures the relevance of our study to the realities of the community. Members of the $\mathrm{CAB}$ with specific expertise in subsections of this study (ie, chronic pain, sexual health etc) are invited to join Community Advisory Working groups that will meet more frequently.

\section{Study team}

We are a diverse team of basic scientists, infectious disease physicians, epidemiologists, social scientists, trainees and community members, including four PRAs, two Indigenous Elders and several organisational partners. Our team also includes a research nurse and research coordinators from the basic, clinical and social sciences. Trainees include undergraduate, graduate, medical students and fellows.

\section{Participant recruitment}

We aim to enrol $n=350$ WLWH and $n=350$ sociodemographically matched HIV-negative women. Among participants, 400/700 will be premenopausal women, while $300 / 700$ will be menopausal. We will preferentially recruit from the $\mathrm{BC}$ samples of CHIWOS ( $\mathrm{n}=356 \mathrm{WLWH}$ ) 




Figure 2 Cell sorting and analysis. Cells will be sorted by flow cytometry into B and T cells. Number of $T$ cells in each subset will be counted (naïve, CM, EM, TD). T cells will be further sorted into CD8+CD28+ (proliferating), CD8+CD28(senescent) and CD4+populations. DNA will be extracted from sorted cells and used for LTL and mtDNA content determination by monochrome multiplex qPCR and nextgeneration sequencing, respectively. $\mathrm{CM}$, central memory; EM, effector memory; LTL, leucocyte telomere length; TD, terminally differentiated.

and CARMA ( $\mathrm{n}=275$ WLWH and n=291 HIV-negative controls) (table 1). CHIWOS and CARMA have an overlap of $n=\sim 130$ BC women and $>95 \%$ of participants have given permission to be contacted for future studies. We will recruit new participants using posters at community centres and clinics, social media outreach and via

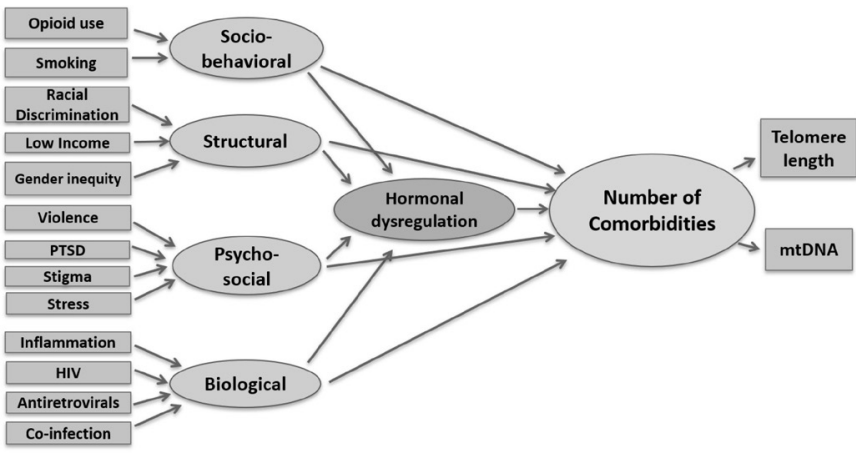

Figure 3 Latent variable structural model. Structural equation modelling will test direct effects, via sociobehavioural (eg, smoking, opioid use), structural (eg, gender inequity, discrimination), psychosocial (eg, violence, PTSD, stigma), and viral (HIV, cART, co-infections) factors and indirect effects via hormonal disturbances, on the latent variables of number of comorbidities, LTL and mtDNA. CART, combination antiretroviral therapy; LTL, leukocyte telomere length; mtDNA, mitochondrial DNA; PTSD, post-traumatic stress disorder. community networks, including through the CAB. This will ensure that HIV-negative participants reflect the sociodemographic profile of HIV-positive participants.

\section{Inclusion criteria}

Cis-gender and trans-gender women living in $\mathrm{BC} \geq 16$ years of age, who can provide written, informed consent in English and attend in-person study visits will be included in this study. Given the collection of biospecimens for hormonal analysis, women who are currently pregnant/ breast feeding will be invited to enrol at least 3 months after pregnancy/cessation of breast feeding.

\section{Data collection}

Eligible participants are asked to provide written, informed consent prior to enrolment. Survey data are collected and stored using the secure Research Electronic Data Capture web service. ${ }^{99} 100$ Biological specimens are processed at the BC Women's Hospital Research Laboratory and then stored in the Côté laboratory. Data are collected during a two-part study visit, one in clinic and one in community (table 2). For in-person visits, we strictly adhere to current COVID-19 safety measures. Whenever possible, community visits are conducted remotely.

The in-clinic portion of the visit takes place first, where research assistants and/or coordinators collect anthropometric data, obtain biological specimens and administer the first series of survey questions (table 3). For menstruating women who are not at the optimum time of their cycle for hormone analyses, additional visit(s) are scheduled. The community visit occurs within 1 month of the clinic visit and includes a detailed questionnaire, based on validated/published tools (tables 4 and 5).

\section{Sample processing}

\section{Cellular outcomes}

Clinical laboratory testing of blood and urine samples is completed by BC Women's Hospital Research Laboratory, including complete blood count, haemoglobin, albumin, creatinine, haemoglobin A1c, aspartate aminotransferase, alanine aminotransferase and non-fasting lipids. Serum samples are assayed by the BC Centre for Disease Control for the presence of $\mathrm{HCV}(\mathrm{Ab}+), \mathrm{HBV}(\mathrm{Ag}+)$, herpes simplex virus-1 and $2(\mathrm{Ab}+)$ infections. We perform qualitative HCV RNA analysis and serology for cytomegalovirus and Epstein-Barr virus IgG. Varicella zoster virus status is determined by history. We also perform hair, saliva and real-time hormonal analyses for estradiol, progesterone, prolactin, luteinising hormone (LH), androstenedione and dehydroepiandrosterone sulfate.

Fluorescence-activated cell sorting on a flow cytometer is used to separate and collect CD8 T cells, CD4 T cells and B cells (figure 2). Total DNA is extracted and mtDNA content is measured by monochrome multiplex qPCR ${ }^{101}$ mtDNA mutations and degree of heteroplasmy are measured by next-generation sequencing using a previously described method. ${ }^{48}$ LTL is measured in CD8 + CD28+ and CD28 cells using a monochrome multiplex 
qPCR assay, as we described previously. ${ }^{102}$ We will investigate the impact of cART interruptions on these markers of cellular ageing based on participant self-reported cART adherence and HIV plasma viral load. Data from CHIWOS indicate that self-reported cART data have high reliability in WLWH. ${ }^{103}$

We use a custom Mesoscale V-Plex panel to assess chronic inflammation, including cytokines (ie, interleukin-6) and C reactive protein. ${ }^{104}$ We also calculate the $\mathrm{C}$ reactive protein/albumin ratio.

We have up to 10 years of data/biospecimens for CARMA participants enrolled in BCC3 to investigate the association between rate of decline in LTL and/or mtDNA content, the development of comorbidities and age at menopause. For those who have undergone curative therapy for HCV, we assess the impact of clearance on markers of cellular ageing. Finally, we explore the longitudinal effects of switching to an integrase strand transfer inhibitor-based cART regime, as we have preliminary data suggesting that these medications may affect mitochondrial health (unpublished). These analyses are based on the first and last blood samples for BCC3/ CARMA participants.

\section{Endocrinology outcomes}

Participants will be categorised as having either 'normal' or 'ever abnormal' ovarian function. 'Abnormal' will be defined as ever having experienced primary ovarian insufficiency, menopause at $<45$ years or amenorrhea for $>1$ consecutive year not related to pregnancy, lactation, birth control, oophorectomy or hysterectomy. Menopause will be defined as no menses for $\geq 1$ year and folliclestimulating hormone $\geq 25 \mathrm{IU} / \mathrm{mL} .{ }^{105} \mathrm{In}$ women with amenorrhea $\geq 3$ months, menopausal status and cause of amenorrhea were determined by doing a urine pregnancy test and measuring estradiol, progesterone, prolactin, LH, androstenedione and dehydroepiandrosterone sulfate. Untimed follicle-stimulating hormone, testosterone and thyroid-stimulating hormone are measured in plasma for all participants. Free progesterone is assessed if thyroidstimulating hormone is abnormal. Average cortisol over the previous month is assayed from the $2.5 \mathrm{~cm}$ of hair closest to the scalp ( 20 hairs). ${ }^{106}$ For menstruating women not using hormonal contraceptives, we measure early follicular phase estradiol (cycle days 2-5) and midluteal phase progesterone (days 21-23 or 7 days before next flow). For postmenopausal women, we measure untimed estrone rather than estradiol.

\section{Data analysis}

Descriptive statistics will be used to summarise all measures. The Mann-Whitney U-test and $\chi^{2}$ or Fisher's exact test will be used to compare data by HIV status.

We will compare the total number of viruses between groups (WLWH vs HIV-negative women) by unpaired t-test or Mann-Whitney tests and the Kruskal-Wallis test when multiple viruses are present. MtDNA mutations will be compared between groups by the unpaired t-test or Mann-Whitney test. Fisher's exact test will be used to compare the presence of heteroplasmy (yes/no). Differences in the measures of cellular ageing (mtDNA and LTL) in immune cell subsets and comorbidities will be compared between groups according to number of viruses $( \pm \mathrm{HIV})$ by Kruskal-Wallis or one-way analysis of variance tests, correcting for multiple comparisons. Associations between number of chronic/latent viruses and mtDNA mutations will be explored using Spearman's or Pearson's correlations. We will examine independent associations between these measures using multivariable linear regression and/or logistic regression, considering demographic, psychosocial and behavioural covariates/confounders. Among WLWH, associations between plasma viral load and cART regimen will be examined by Kruskal-Wallis test, with Dunn's adjustment.

For longitudinal analyses, within-individual changes in markers of cellular ageing will be assessed using a paired t-test or a Wilcoxon test. Survival analyses will be used to examine the rate of LTL or mtDNA decline and age at menopause. This analysis will be restricted to women $\geq 35$ years, using this age as time 0 . Estimated age at menopause will be the outcome and data will be censored at last age if menopause has not been reached, regressing on rate of decline in LTL and mtDNA.

Associations between history of prolonged secondary amenorrhea (outcome variable) and HIV status will be examined using multivariable logistic regression, adjusting for potential founders (ie, age, smoking, opioid use). Multiple linear (estrone, estradiol, testosterone, cortisol) and logistic regression (progesterone; dichotomised at $3 \mathrm{ng} / \mathrm{mL}$ as the accepted threshold to confirm if a cycle is ovulatory) ${ }^{107}$ will estimate the association between hormone levels (outcome variable) and HIV status (predictor), adjusting for confounders.

Poisson regression will be used to investigate the relationship between history of prolonged secondary amenorrhea (yes/no; dependent variable) and number of comorbidities (0-10). We will use linear regression to determine associations between history of prolonged secondary amenorrhea and LTL/mtDNA. Models will be adjusted for covariates/confounders. We will use Poisson regression to examine the association of estradiol levels and number of comorbidities. Multivariable linear regression will be used to assess the association between each hormone of interest (ie, levels of estrone, estradiol, progesterone, testosterone, cortisol) and cellular ageing.

Unadjusted and adjusted linear regression will estimate the regression coefficients of number of comorbidities (primary outcome) and LTL/mtDNA content (secondary outcome). Any history of prolonged amenorrhea will be the proposed mediator.

The impact of sociostructural behaviour determinants on number of comorbidities and cellular ageing will be explored using structural equation modelling (figure 3). The model will be assessed for goodness of fit using the $\chi^{2}$ test (acceptable fit $=\mathrm{p}<0.05$ ), Root mean square error of approximation (acceptable fit=score $<0.05,90 \%$ CI of 0.02 
to 0.08 ) and Comparative Fit Index (acceptable fit=score $>0.9){ }^{108}$

Analyses will be performed using GraphPad Prism, SPSS v25, R, SAS v9.4 and Mplus.

With a sample of 350 per group, we will have sufficient power for all proposed analyses (see online supplemental file 1).

\section{Ethics and dissemination}

This study has been approved by the UBC Children's and Women's Hospital Research Ethics Board (H19-00896).

In collaboration with community partners, PRAs and knowledge users, we will share research findings through peer-reviewed publications, conference presentations, Sharing Circles, community forums, scientific cafes and healthcare provider events. To facilitate knowledge exchange, we will create an atmosphere for consultation and partnership. Elders will guide us in Indigenising the process of knowledge translation. Results, protocols and procedural documents are found on our website https:// hivhearmeca/resources/. We also share study updates with WLWH, academics and our many community partners (online supplemental table S2) on Twitter @HIV_ HEAR_me. Biospecimens and questionnaire data can be accessed according to our data sharing plan (online supplemental file 1).

We present here the protocol for an innovative approach to cell-to-society, community-based research for healthy ageing among WLWH. Our diverse research team is built from a mutual desire to improve the lives and health outcomes of WLWH. Central to this partnership is a shared understanding of the value of each team member and their respective field of expertise, be it clinical, bench science, social sciences or living and lived experience as well as the diversity of our participants. This research is powerful in its ability to build capacity and empower all team members, including PRAs. The results of this study will be used to guide clinical practice, public health policy and activism, improving the ageing experience, health outcomesy and longevity of WLWH and all women across BC and beyond.

\footnotetext{
Author affiliations

${ }^{1}$ Experimental Medicine, The University of British Columbia Faculty of Medicine, Vancouver, British Columbia, Canada

${ }^{2}$ British Columbia Women's Hospital and Health Centre Women's Health Research Institute, Vancouver, British Columbia, Canada

${ }^{3}$ Faculty of Health Sciences, Simon Fraser University, Burnaby, British Columbia, Canada

${ }^{4}$ Epidemiology and Population Health, BC Centre for Excellence in HIV/AIDS, Vancouver, British Columbia, Canada

${ }^{5}$ Division of Infectious Diseases, Children's Hospital of Eastern Ontario, Ottawa, Ontario, Canada

${ }^{6}$ Oak Tree Clinic, BC Women's Hospital and Health Centre, Vancouver, British Columbia, Canada

${ }^{7}$ Faculty of Medicine, The Kirby Institute, Sydney, New South Wales, Australia ${ }^{8}$ Obstetrics and Gynecology, BC Women's Hospital and Health Centre, Vancouver, British Columbia, Canada

${ }^{9}$ Medicine, The University of British Columbia Faculty of Medicine, Vancouver, British Columbia, Canada

${ }^{10}$ Afro-Caribbean Positive Network of BC, Vancouver, British Columbia, Canada
}

${ }^{11}$ Bear Rock Consulting, Lone Butte, British Columbia, Canada

${ }^{12}$ Division of Infectious Diseases, The University of British Columbia Faculty of Medicine, Vancouver, British Columbia, Canada

${ }^{13}$ Pathology and Laboratory Medicine, The University of British Columbia Faculty of Medicine, Vancouver, British Columbia, Canada

${ }^{14}$ Centre for Menstrual Cycle and Ovulatory Research, The University of British Columbia Faculty of Medicine, Vancouver, British Columbia, Canada

${ }^{15}$ School of Population and Public Health, University of British Columbia, Vancouver, British Columbia, Canada

Twitter Shayda A Swann @HIV_HEAR_me and Melanie C M Murray @ DrMelanieMurray

Acknowledgements The BC CARMA-CHIWOS Collaboration (BCC3) study thanks the participants, national team of investigators, community partners, PRAs, research staff members and funders of the Canadian HIV Women's Sexual and Reproductive Health (CHIWOS) cohort study, including the co-principal investigators, Drs Mona Loutfy, Alexandra de Pokomandy and Angela Kaida. We thank and acknowledge the same members within the CARMA team, including its co-PIs, HCFC, MCMM, NP, Deborah Money, Hugo Soudeyns and Ari Bitnun. We also thank and acknowledge Sarah Chown and YouthCo for contributing to the design of this study. All figures were created using BioRender.com.

Contributors HCFC, MCMM and AK led the conceptualisation and design of this study. SAS led the authorship of this manuscript. JB, ARC, CE, EJM, VN, NP, JP and JS contributed to study design. This manuscript was critically revised by HCFC, MCMM, AK, JB, ARC, AC, TG, RG, EK, ML, VL, EJM, PM, VN, SN, DP, NP, TP, JCP, JS and ST.

Funding This work is being supported by a 5-year (2019-2024) Canadian Institutes of Health Research (CIHR) Project Grant (grant number BCA-408242 to HCFC, MCMM, AK, NP), a 5-year CIHR Project Grant (grant number 175006 to MCMM, JB, AC, HCFC, CE, AK, EK, Carmen Logie, Mona Loutfy, VN, NP, JCP, KS, JS), a 3-year CIHR HIV/AIDS Community-Based Research Grant (grant number 170103 to MCMM, VN, JB, AC, Sarah Chown, HCFC, CE, AK, EK, PM, NP, JCP, KS, JS), a 1-year Simon Fraser University 2020 Community Engagement Initiative Grant (grant to $\mathrm{AK})$.

Competing interests None declared.

Patient consent for publication Not required.

Provenance and peer review Not commissioned; externally peer reviewed.

Supplemental material This content has been supplied by the author(s). It has not been vetted by BMJ Publishing Group Limited (BMJ) and may not have been peer-reviewed. Any opinions or recommendations discussed are solely those of the author(s) and are not endorsed by BMJ. BMJ disclaims all liability and responsibility arising from any reliance placed on the content. Where the content includes any translated material, BMJ does not warrant the accuracy and reliability of the translations (including but not limited to local regulations, clinical guidelines, terminology, drug names and drug dosages), and is not responsible for any error and/or omissions arising from translation and adaptation or otherwise.

Open access This is an open access article distributed in accordance with the Creative Commons Attribution Non Commercial (CC BY-NC 4.0) license, which permits others to distribute, remix, adapt, build upon this work non-commercially, and license their derivative works on different terms, provided the original work is properly cited, appropriate credit is given, any changes made indicated, and the use is non-commercial. See: http://creativecommons.org/licenses/by-nc/4.0/.

ORCID iD

Shayda A Swann http://orcid.org/0000-0001-7507-3747

\section{REFERENCES}

1 Burchell AN, Raboud J, Donelle J, et al. Cause-specific mortality among HIV-infected people in Ontario, 1995-2014: a populationbased retrospective cohort study. CMAJ Open 2019;7:E1-7.

2 Kaplan-Lewis E, Aberg JA, Lee M. Aging with HIV in the art era. Semin Diagn Pathol 2017;34:384-97.

3 Harris CM, McKenzie R, Nayak S, et al. Graying of the HIV epidemic: a challenge for inpatient medicine providers. $J$ Community Hosp Intern Med Perspect 2015;5:29428.

4 World Health Organization. World report on ageing and health. Luxembourg, 2015. Available: www.who.int [Accessed 11 Sep 2020]. 
5 Dev R, Zaslavsky O, Cochrane B, et al. Healthy aging through the lens of community-based practitioners: a focus group study. BMC Geriatr 2020;20:211.

6 Haddad N, Robert A, Weeks A, et al. Hiv in Canada-surveillance report, 2018. Can Commun Dis Rep 2019;45:304-12.

7 Bc centre for excellence in HIV/AIDS. HIV monitoring Quarterly report for British Columbia: fourth quarter 2019 Vancouver, 2019. Available: http://stophivaids.ca/qmr/2019-Q4/\#/bc [Accessed $08 \mathrm{Jul}$ 2020].

8 UNAIDS. AIDSinfo. Available: http://aidsinfo.unaids.org/ [Accessed 06 May 2020].

9 Wong J, Wong E, Mazo O. HIV annual report 2017. Vancouver, 2019. Available: http://www.bccdc.ca/health-professionals/datareports/hiv-aids-reports [Accessed 07 May 2020].

10 Table 2 aboriginal female population by province or territory, Canada, 2006. Available: https://www150.statcan.gc.ca/n1/pub/89503-x/2010001/article/11442/tbl/tbl002-eng.htm [Accessed 07 May 2020].

11 Patel P, Borkowf CB, Brooks JT, et al. Estimating per-act HIV transmission risk: a systematic review. AIDS 2014;28:1509-19.

12 Richardson ET, Collins SE, Kung T, et al. Gender inequality and HIV transmission: a global analysis. J Int AIDS Soc 2014;17:19035.

13 Dunkle KL, Decker MR, Violence G-B. Gender-based violence and HIV: reviewing the evidence for links and causal pathways in the general population and high-risk groups. Am J Reprod Immunol 2013;69 (suppl 1):20-6.

14 Carter A, Greene S, Nicholson V, et al. 'It's a very isolating world' : the journey to HIV care for women living with HIV in British Columbia, Canada. Gend Place Cult 2016;23:941-54.

15 Kronfli N, Lacombe-Duncan A, Wang Y, et al. Access and engagement in HIV care among a national cohort of women living with HIV in Canada. AIDS Care 2017;29:1235-42.

16 Palella FJ, Hart R, Armon C, et al. Non-AIDS comorbidity burden differs by sex, race, and insurance type in aging adults in HIV care. AIDS 2019;33:2327-35.

17 Kendall CE, Wong J, Taljaard M, et al. A cross-sectional, populationbased study measuring comorbidity among people living with HIV in Ontario. BMC Public Health 2014;14:161.

18 Hogg RS, Eyawo O, Collins AB, et al. Health-adjusted life expectancy in HIV-positive and HIV-negative men and women in British Columbia, Canada: a population-based observational cohort study. Lancet HIV 2017;4:e270-6.

19 Patterson S, Cescon A, Samji H, et al. Life expectancy of HIVpositive individuals on combination antiretroviral therapy in Canada. BMC Infect Dis 2015;15:274

20 Jarrin I, Moreno S, Ingle S, et al. Sex differences in overall and cause-specific mortality among HIV-infected adults on antiretroviral therapy in Europe, Canada and the US. Antivir Ther 2015;20:21-8.

21 Centers for Disease Control and Prevention. Intersection of intimate partner violence and HIV in women. Atlanta, 2014. Available: https:// www.cdc.gov/violenceprevention/pdf/ipv/13_243567_Green_AAGa.pdf [Accessed 07 May 2020].

22 Wagner AC, Jaworsky D, Logie $\mathrm{CH}$, et al. High rates of posttraumatic stress symptoms in women living with HIV in Canada. PLoS One 2018;13:e0200526.

23 Zhang Y, Wilson TE, Adedimeji A, et al. The impact of substance use on adherence to antiretroviral therapy among HIV-infected women in the United States. AIDS Behav 2018;22:896-908.

24 Curno MJ, Rossi S, Hodges-Mameletzis I, et al. A systematic review of the inclusion (or exclusion) of women in HIV research: from clinical studies of antiretrovirals and vaccines to cure strategies. $J$ Acquir Immune Defic Syndr 2016;71:181-8.

25 Loutfy M, de Pokomandy A, Kennedy VL, et al. Cohort profile: the Canadian HIV women's sexual and reproductive health cohort study (CHIWOS). PLoS One 2017;12:e0184708.

26 Rieker PP, Bird CE, Moen P. Rethinking gender differences in health: why we need to integrate social and biological perspectives. $J$ Gerontol B Psychol Sci Soc Sci 2005;60 Spec No 2:S40-7.

27 Remis RS, Liu J, Loutfy M, et al. The epidemiology of sexually transmitted co-infections in HIV-positive and HIV-negative AfricanCaribbean women in Toronto. BMC Infect Dis 2013;13:550.

28 Rockstroh J. Hiv and HCV coinfections in women: all the same or something different? 2017. Available: http://regist2.virologyeducation.com/2017/7hivwomen/08_Rockstroh.pdf [Accessed 07 May 2020].

29 Kourtis AP, Bulterys M, Hu DJ, et al. HIV-HBV coinfection--a global challenge. N Engl J Med 2012;366:1749-52.

30 Freeman EE, Weiss HA, Glynn JR, et al. Herpes simplex virus 2 infection increases HIV acquisition in men and women: systematic review and meta-analysis of longitudinal studies. AIDS 2006;20:73-83.
31 Singh L, Mishra S, Prasanna S, et al. Seroprevalence of torch infections in antenatal and HIV positive patient populations. Med J Armed Forces India 2015;71:135-8.

32 Dreyer G. Clinical implications of the interaction between HPV and HIV infections. Best Pract Res Clin Obstet Gynaecol 2018;47:95-106.

33 Badial RM, Dias MC, Stuqui B, et al. Detection and genotyping of human papillomavirus (HPV) in HIV-infected women and its relationship with HPV/HIV co-infection. Medicine 2018;97:e9545.

34 Boldogh I, Albrecht T, Porter DD. Baron S, ED. medical microbiology. Galveston: University of Texas Medical Branch at Galveston, 1996. https://www.ncbi.nlm.nih.gov/books/NBK8538/

35 Strader DB. Coinfection with HIV and hepatitis $C$ virus in injection drug users and minority populations. Clin Infect Dis 2005;41 (Suppl 1):S7-13.

36 Wang F, Kieff E. Medical Virology. In: Harrison's Principles of Internal Medicine. New York: McGraw-Hill, 2012: 1437-8.

37 Lurain NS, Hanson BA, Hotton AL, et al. The association of human cytomegalovirus with biomarkers of inflammation and immune activation in HIV-1-infected women. AIDS Res Hum Retroviruses 2016;32:134-43.

38 Fülöp T, Larbi A, Pawelec G. Human T cell aging and the impact of persistent viral infections. Front Immunol 2013;4:271.

39 Sereti I, Altfeld M. Immune activation and HIV: an enduring relationship HHS public access. Curr Opin HIV AIDS 2016;11:129-30.

40 Weiskopf D, Weinberger B, Grubeck-Loebenstein B. The aging of the immune system. Transpl Int 2009;22:1041-50.

41 Vitlic A, Lord JM, Phillips AC. Stress, ageing and their influence on functional, cellular and molecular aspects of the immune system. Age 2014;36:1169-85.

42 Hotamisligil GS. Inflammation and metabolic disorders. Nature 2006;444:860-7.

43 Wallace DC. Mitochondrial DNA mutations in disease and aging. Environ Mol Mutagen 2010;51

44 López-Otín C, Blasco MA, Partridge L, et al. The hallmarks of aging. Cell 2013;153:1194-217.

$45 \mathrm{Kim} \mathrm{H}-\mathrm{J}$, Cantor H. CD4 T-cell subsets and tumor immunity: the helpful and the not-so-helpful. Cancer Immunol Res 2014;2:91-8.

46 Fang P, Li X, Dai J, et al. Immune cell subset differentiation and tissue inflammation. J Hematol Oncol 2018;11:1-22.

47 Stefano GB, Bjenning C, Wang F, et al. Mitochondrial heteroplasmy. Adv Exp Med Biol 2017;982:577-94.

48 Ziada AS, Lu MY, Ignas-Menzies J, et al. Mitochondrial DNA somatic mutation burden and heteroplasmy are associated with chronological age, smoking, and HIV infection. Aging Cell 2019;18:e13018.

49 Hulgan T, Gerschenson M. HIV and mitochondria: more than just drug toxicity. J Infect Dis 2012;205:1769-71 https://www.ncbi.nlm. nih.gov/pmc/articles/PMC3357135/

50 Zhan Y, Hägg S. Telomere length and cardiovascular disease risk. Curr Opin Cardiol 2019;34:270-4.

51 Zanet DL, Thorne A, Singer J, et al. Association between short leukocyte telomere length and HIV infection in a cohort study: no evidence of a relationship with antiretroviral therapy. Clin Infect Dis 2014;58:1322-32.

52 Pathai S, Lawn SD, Gilbert CE, et al. Accelerated biological ageing in HIV-infected individuals in South Africa: a case-control study. AIDS 2013;27:2375-84.

53 Bellon M, Nicot C. Telomere dynamics in immune senescence and exhaustion triggered by chronic viral infection. Viruses 2017;9. doi:10.3390/v9100289. [Epub ahead of print: 05 Oct 2017].

54 King EM, Albert AY, Murray MCM. HIV and amenorrhea: a metaanalysis. AIDS 2019;33:483-91.

55 Valiaveettil C, Loutfy M, Kennedy VL, et al. High prevalence of abnormal menstruation among women living with HIV in Canada. PLoS One 2019;14:e0226992.

56 Zanni MV, Currier JS, Kantor A, et al. Correlates and timing of reproductive aging transitions in a global cohort of midlife women with human immunodeficiency virus: insights from the REPRIEVE trial. J Infect Dis 2020;222:S20-30.

57 Sokalski KM, Chu J, Mai AY, et al. Endocrine abnormalities in HIVinfected women are associated with peak viral load - the children and women: antiretrovirals and markers of aging (CARMA) cohort. Clin Endocrinol 2016;84:452-62.

58 Väänänen HK, Härkönen PL. Estrogen and bone metabolism. Maturitas 1996;23 (Suppl):S65-9.

59 Riggs BL. The mechanisms of estrogen regulation of bone resorption. J Clin Invest 2000;106:1203-4.

60 Prior JC. Progesterone for the prevention and treatment of osteoporosis in women. Climacteric 2018;21:366-74. 
61 Ahmed SB, Ramesh S. Sex hormones in women with kidney disease. Nephrol Dial Transplant 2016;31:1787-95.

62 Valdivielso JM, Jacobs-Cachá C, Soler MJ. Sex hormones and thei influence on chronic kidney disease. Curr Opin Nephrol Hypertens 2019;28:1-9.

63 Neugarten J, Golestaneh L. Gender and the prevalence and progression of renal disease. Adv Chronic Kidney Dis 2013;20:390-5.

64 Palmisano BT, Zhu L, Stafford JM. Role of estrogens in the regulation of liver lipid metabolism. Adv Exp Med Biol 2017:227-56.

65 Chen KL, Madak-Erdogan Z. Estrogens and female liver health. Steroids 2018;133:38-43.

66 Pu D, Tan R, Yu Q, et al. Metabolic syndrome in menopause and associated factors: a meta-analysis. Climacteric 2017;20:583-91.

67 Hara Y, Waters EM, McEwen BS, et al. Estrogen effects on cognitive and synaptic health over the lifecourse. Physiol Rev 2015;95:785-807.

68 Clegg D, Hevener AL, Moreau KL, et al. Sex hormones and cardiometabolic health: role of estrogen and estrogen receptors. Endocrinology 2017:158:1095-105.

69 Klinge CM. Estrogenic control of mitochondrial function and biogenesis. J Cell Biochem 2008;105:1342-51.

70 Shin Y-A, Lee K-Y. Low estrogen levels and obesity are associated with shorter telomere lengths in pre- and postmenopausal women. $J$ Exerc Rehabil 2016;12:238-46.

71 Seyfried O, Hester J. Opioids and endocrine dysfunction. Br J Pain 2012;6:17-24.

72 Sherin JE, Nemeroff CB. Post-Traumatic stress disorder: the neurobiological impact of psychological trauma. Dialogues Clin Neurosci 2011;13:263-78.

73 Tweed JO, Hsia SH, Lutfy K, et al. The endocrine effects of nicotine and cigarette smoke. Trends Endocrinol Metab 2012;23:334-42.

74 McEwen BS. Neurobiological and systemic effects of chronic stress. Chronic Stress 2017;1:247054701769232.

75 Tsigos C, Chrousos GP. Hypothalamic-Pituitary-Adrenal axis, neuroendocrine factors and stress. J Psychosom Res 2002;53:865-71.

76 Skerritt L, de Pokomandy A, Burchell AN. Trends and determinants of discussing reproductive health goals with healthcare providers among women living with HIV, 2018. North American primary care research group annual meeting. Available: http://www.chiwos. ca/wp-content/uploads/2019/05/NAPCRG-2018_ReproductiveDiscussions-poster_Skerritt FINAL-1.pdf

77 Granville L, Pregler J. Women's sexual health and aging. J Am Geriatr Soc 2018;66:595-601.

78 Waite LJ, Laumann EO, Das A, et al. Sexuality: measures of partnerships, practices, attitudes, and problems in the National social life, health, and aging study. J Gerontol B Psychol Sci Soc Sci 2009;64 (Suppl 1):i56-66.

79 Rodger AJ, Cambiano V, Bruun T, et al. Sexual activity without condoms and risk of HIV transmission in serodifferent couples when the HIV-positive partner is using suppressive antiretroviral therapy. JAMA 2016;316:171-81.

80 Kaida A, Carter A, de Pokomandy A, et al. Sexual inactivity and sexual satisfaction among women living with HIV in Canada in the context of growing social, legal and public health surveillance. J Int AIDS Soc 2015;18:20284.

81 Carter SE, Ong ML, Simons RL, et al. The effect of early discrimination on accelerated aging among African Americans. Health Psychol 2019;38:1010-3.

82 Guedes DT, Vafaei A, Alvarado BE, et al. Experiences of violence across life course and its effects on mobility among participants in the International mobility in aging study. BMJ Open 2016;6:e012339.

83 Byhoff E, Tripodis Y, Freund KM, et al. Gender differences in social and behavioral determinants of health in aging adults. J Gen Intern Med 2019;34:2310-2.

84 Edmonds GW, Hampson SE, Côté HCF, et al. Childhood personality, betrayal trauma, and leukocyte telomere length in adulthood: a lifespan perspective on conscientiousness and betrayal traumas as predictors of a biomarker of cellular aging. Eur J Pers 2016;30:426-37.

85 Logie C, James L, Tharao W, et al. Associations between HIVrelated stigma, racial discrimination, gender discrimination, and depression among HIV-positive African, Caribbean, and black women in Ontario, Canada. AIDS Patient Care STDS 2013;27:114-22.

86 Logie $\mathrm{CH}$, Kaida A, de Pokomandy A, et al. Prevalence and correlates of forced sex as a self-reported mode of HIV acquisition among a cohort of women living with HIV in Canada. $J$ Interpers Violence 2020;35:5028-63.
87 Carter AJ, Bourgeois S, O'Brien N, et al. Women-specific HIV/ AIDS services: identifying and defining the components of holistic service delivery for women living with HIV/AIDS. J Int AIDS Soc 2013;16:17433.

88 O'Brien N, Greene S, Carter A, et al. Envisioning women-centered HIV care: perspectives from women living with HIV in Canada. Womens Health Issues 2017:27:721-30.

89 Morolake O, Stephens D, Welbourn A. Greater involvement of people living with HIV in health care. J Int AIDS Soc 2009;12:4-7.

90 Carter A, Greene S, Nicholson V, et al. Breaking the glass ceiling: increasing the meaningful involvement of women living with HIV/ AIDS (MIWA) in the design and delivery of HIV/AIDS services. Health Care Women Int 2015;36:936-64.

91 Namiba A, Orza L, Bewley S, et al. Ethical, strategic and meaningful involvement of women living with HIV starts at the beginning. $J$ Virus Erad 2016;2:110-1.

92 The first nations principles of OCAPTM what is OCAPTM? Available: http://www.fnigc.ca/ocap.html [Accessed 08 May 2020].

93 Flicker S, O'Campo P, Monchalin R, et al. Research done in "a good way": the importance of indigenous elder involvement in HIV community-based research. Am J Public Health 2015;105:1149-54.

94 Peltier D, Martin C, Masching R, et al. A journey of doing research "in a good way": partnership, ceremony, and reflections contributing to the care and wellbeing of indigenous women living with HIV in Canada. Int Indig Policy J 2020;11:1-19 11.https://ojs.lib.uwo.ca/ index.php/iipj/article/view/8215/11011

95 Loutfy M, Greene S, Kennedy VL, et al. Establishing the Canadian HIV women's sexual and reproductive health cohort study (CHIWOS): operationalizing community-based research in a large national quantitative study. BMC Med Res Methodol 2016;16:1-9.

96 Kaida A, Carter A, Nicholson V, et al. Hiring, training, and supporting peer research associates: operationalizing community-based research principles within epidemiological studies by, with, and for women living with HIV. Harm Reduct J 2019;16:47.

97 Setting new directions to support Indigenous research and research training in Canada, 2019. Available: www.canada.ca/crcc [Accessed 03 Sep 2020]

98 Truth and reconciliation Commission of Canada: calls to action. Winnipeg, 2015. Available: http://trc.ca/assets/pdf/Calls_to_Action English2.pdf [Accessed 03 Sep 2020].

99 Harris PA, Taylor R, Thielke R, et al. Research electronic data capture (REDCap)--a metadata-driven methodology and workflow process for providing translational research informatics support. $J$ Biomed Inform 2009;42:377-81.

100 Harris PA, Taylor R, Minor BL, et al. The REDCap Consortium: building an international community of software platform partners. $J$ Biomed Inform 2019;95:103208.

101 Hsieh AYY, Budd M, Deng D, et al. A monochrome multiplex realtime quantitative PCR assay for the measurement of mitochondrial DNA content. J Mol Diagn 2018;20:612-20.

102 Hsieh AYY, Saberi S, Ajaykumar A, et al. Optimization of a relative telomere length assay by monochromatic multiplex real-time quantitative PCR on the LightCycler 480: sources of variability and quality control considerations. J Mol Diagn 2016;18:425-37.

103 Carter A, de Pokomandy A, Loutfy M, et al. Validating a selfreport measure of HIV viral suppression: an analysis of linked questionnaire and clinical data from the Canadian HIV women's sexual and reproductive health cohort study. BMC Res Notes 2017:10:138.

104 Koelman L, Pivovarova-Ramich O, Pfeiffer AFH, et al. Cytokines for evaluation of chronic inflammatory status in ageing research reliability and phenotypic characterisation. Immun Ageing 2019;16:11

105 Cejtin HE, Kalinowski A, Bacchetti P, et al. Effects of human immunodeficiency virus on protracted amenorrhea and ovarian dysfunction. Obstet Gynecol 2006;108:1423-31.

106 Greff MJE, Levine JM, Abuzgaia AM, et al. Hair cortisol analysis: an update on methodological considerations and clinical applications. Clin Biochem 2019;63:1-9.

107 Prior JC, Naess M, Langhammer A, et al. Ovulation prevalence in women with spontaneous normal-length menstrual cycles - a population-based cohort from HUNT3, Norway. PLoS One 2015;10:e0134473.

108 Kline RB. Principles and practice of structural equation modeling.4th edn. New York: Guildford Press, 2015. https://www. guilford.com/books/Principles-and-Practice-of-Structural-EquationModeling/Rex-Kline/9781462523344

109 The practical guide identification, evaluation and treatment of overweight and obesity in adults, 2000. Available: https://www. nhlbi.nih.gov/files/docs/guidelines/prctgd_c.pdf [Accessed 16 Jun 2020]. 
110 Organization WH. Waist Circumference and Waist-Hip Ratio: Report of a WHO Expert Consultation. Ge: World Health Organization, 2011.

111 Sterling RK, Lissen E, Clumeck N, et al. Development of a simple noninvasive index to predict significant fibrosis in patients with HIV/ HCV coinfection. Hepatology 2006;43:1317-25.

112 Snyder N, Gajula L, Xiao S-Y, et al. Apri: an easy and validated predictor of hepatic fibrosis in chronic hepatitis C. J Clin Gastroenterol 2006;40:535-42.

113 Tangri N, Stevens LA, Griffith J, et al. A predictive model for progression of chronic kidney disease to kidney failure. JAMA 2011;305:1553-9.

114 Anderson TJ, Grégoire J, Hegele RA, et al. 2012 update of the Canadian cardiovascular Society guidelines for the diagnosis and treatment of dyslipidemia for the prevention of cardiovascular disease in the adult. Can J Cardiol 2013;29:151-67.

115 Anderson TJ, Grégoire J, Pearson GJ, et al. Canadian cardiovascular society guidelines for the management of dyslipidemia for the prevention of cardiovascular disease in the adult. Can J Cardiol 2016;2016:1263-82.

116 Radloff LS. The CES-D scale. Appl Psychol Meas 1977;1:385-401.

117 Zhang W, O'Brien N, Forrest JI, et al. Validating a shortened depression scale (10 item CES-D) among HIV-positive people in British Columbia, Canada. PLoS One 2012;7:e40793.

118 Spitzer RL, Kroenke K, Williams JBW, et al. A brief measure for assessing generalized anxiety disorder: the GAD-7. Arch Intern Med 2006;166:1092-7.

119 Lang AJ, Stein MB. An abbreviated PTSD checklist for use as a screening instrument in primary care. Behav Res Ther 2005;43:585-94.

120 Babor TF, Higgins-Biddle JC, Saunders JB. The alcohol use disorders identification test guidelines for use in primary care. Geneva, 2001. Available: https://apps.who.int/iris/bitstream/handle/ 10665/67205/WHO_MSD_MSB_01.6a.pdf?sequence=1 [Accessed 17 Jun 2020].

121 Canadian longitudinal study on aging. Available: https://www.clsaelcv.ca/ [Accessed 11 May 2020].

122 Adimora AA, Ramirez C, Benning L, et al. Cohort profile: the women's Interagency HIV study (WIHS). Int J Epidemiol 2018;47:393-4.

123 Santoro N, Sutton-Tyrrell K. The swan song: study of women's health across the nation's recurring themes. Obstet Gynecol Clin North Am 2011;38:417-23.

124 North American Menopause Society. Menopause health questionnaire. Cleveland, 2005. Available: https://www.menopause. org/docs/default-document-library/questionnaire.pdf?sfvrsn= 90fd425b 0 [Accessed 02 Nov 2020].

125 Taylor JF, Rosen RC, Leiblum SR. Self-Report assessment of female sexual function: psychometric evaluation of the brief index of sexual functioning for women. Arch Sex Behav 1994;23:627-43.
126 Meston C, Trapnell P. Development and validation of a five-factor sexual satisfaction and distress scale for women: the sexual satisfaction scale for women (SSS-W). J Sex Med 2005;2:66-81.

127 Pulerwitz J, Gortmaker SL, DeJong W. Measuring sexual relationship power in HIV/STD research. Sex Roles 2000;42:637-60.

128 Logie $\mathrm{CH}$, Marcus N, Wang Y, et al. A longitudinal study of associations between HIV-related stigma, recent violence and depression among women living with HIV in a Canadian cohort study. J Int AIDS Soc 2019;22:e25341.

129 Berger BE, Ferrans CE, Lashley FR. Measuring stigma in people with HIV: psychometric assessment of the HIV stigma scale. Res Nurs Health 2001;24:518-29.

130 Reinius M, Wettergren L, Wiklander M, et al. Development of a 12 -Item short version of the HIV stigma scale. Health Qual Life Outcomes 2017;15:115.

131 Logie CH, Lacombe-Duncan A, Wang Y, et al. Pathways from HIVrelated stigma to antiretroviral therapy measures in the HIV care cascade for women living with HIV in Canada. J Acquir Immune Defic Syndr 2018;77:144-53.

132 Krieger N, Smith K, Naishadham D, et al. Experiences of discrimination: validity and reliability of a self-report measure for population health research on racism and health. Soc Sci Med 2005:61:1576-96.

133 Latkin C, Srikrishnan AK, Yang C, et al. The relationship between drug use stigma and HIV injection risk behaviors among injection drug users in Chennai, India. Drug Alcohol Depend 2010;110:221-7.

134 Kim S, Mazza J, Reliability MJ. Reliability, validity, and item response of MOS social support score among incarcerated women. Women Crim Justice 2014;24:1-21.

135 Rossen EK, Gruber KJ. Development and psychometric testing of the relocation self-efficacy scale. Nurs Res 2007;56:244-51.

136 Wagnild G. A review of the resilience scale. J Nurs Meas 2009;17:105-13.

137 Ware J, Kosinski M, Keller SD. A 12-Item short-form health survey: construction of scales and preliminary tests of reliability and validity. Med Care 1996;34:220-33.

138 Canada.ca. The household food security survey module (HFSSM). Available: https://www.canada.ca/en/health-canada/services/ food-nutrition/food-nutrition-surveillance/health-nutrition-surveys/ canadian-community-health-survey-cchs/household-foodinsecurity-canada-overview/household-food-security-surveymodule-hfssm-health-nutrition-surveys-health-canada.html [Accessed 17 Jun 2020].

139 Campbell A. Developing a culturally safe and approprial mobile health program with and for Indigenous people living with HIV: community collaboration and questionnaire validation, 2020

140 Hill PL, Edmonds GW, Peterson M, et al. Purpose in life in emerging adulthood: development and validation of a new brief measure. $J$ Posit Psychol 2016;11:237-45.

141 World Health Organization. Survey tool and guidance: rapid, simple, flexible behavioural insights on COVID-19, 2020. Available: http:// www.euro.who.int/pubrequest [Accessed 22 Jun 2020]. 